Advances in Experimental Medicine and Biology, 624, 89-103. doi: 10.1007/978-0-387-77574-6_8

8. Genomic Classification of Cutaneous Melanoma (2015). Cell, 161 (7), 1681-1696. doi: 10.1016/j.cell.2015.05.044

9. Jemal, A., Saraiya, M., Patel, P., Cherala, S. S., Barnholtz-Sloan, J., Kim, J. et. al (2011). Recent trends in cutaneous melanoma incidence and death rates in the United States, 1992 2006. Journal of the American Academy of Dermatology, 65 (5), S17.e1-S17.e11. doi: 10.1016/j.jaad.2011.04.032

10. Watson, M., Thomas, C. C., Massetti, G. M., McKenna, S., Gershenwald, J. E., Laird, S. (2015). CDC Grand Rounds:
Prevention and Control of Skin Cancer. MMWR. Morbidity and Mortality Weekly Report, 64 (47), 1312-1314. doi: 10.15585/ mmwr.mm6447a2

11. Kotenko, K. (2011). Malignant tumors of the skin in Ukraine. Zdorov'ia Ukrainy, 3, 28-29.

12. Vorobiov, A., Protasova, A. (2010). General screening questions. Practical Oncology, 11 (2), 53-59.

13. Aitken, J. F., Youl, P. H., Janda, M., Lowe, J. B, Ring, I. T., Elwood, M. (2005). Increase in skin cancer screening during a community-based randomized intervention trial. International Journal of Cancer, 118 (4), 1010-1016. doi: 10.1002/ijc.21455

Рекомендовано до публікачії д-р мед. наук, професор Коломоєиь М. Ю.

Дата надходження рукопису 25.02.2016

Oshyvalova Olena, $\mathrm{PhD}$, Senior Research Fellow, Scientific Department of medical care, State Scientific Institution "Scientific and Practical Centre of Preventive and Clinical Medicine" the State Administration, Verchnya str., 5, Kyiv, Ukraine, 01014

E-mail: ochivalova@mail.ru

UDC 616.72-002-021.5-053.2-07:612.017

DOI: $10.15587 / 2313-8416.2016 .64834$

\title{
THE STATE OF IMMUNOLOGICAL REACTIVITY AND NONSPECIFIC PROTECTION FACTOR (LYSOZYME) IN CHILDREN WITH REACTIVE ARTHRITIS
}

\section{(C) V. Savvo, T. Tverdohleb}

\begin{abstract}
Aim. An improvement of diagnostics and prognostication of ReA clinical course in children on the base of studying the immunological reactivity and non-specific protection factor (lysozyme).

Materials and methods. Examination of children took place in the municipal children's cardiorheumatologic department of MHPI “Kharkov municipal children's clinical hospital № 24” and municipal children's polyclinic of the Kharkov city (№ 1, 2, 7, 12, 13, 14, 23).

40 children with ReA underwent immunological examinations, detection of sIgA in the saliva and lysozyme in the blood serum in acute period and in 9-12 months after the beginning of disease. 19 children (47,5\%) - 2-6 years old, 21 children (52,5\%) - 7-14 years old. Boys - $22(55,0 \%)$, girls - 18 (45,0\%). The mean age of children in group was

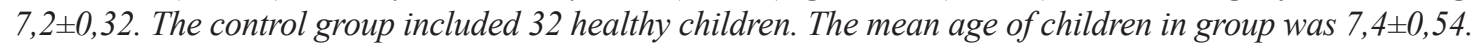

The ReA diagnosis was set according to the order of Ukrainian MHP of 19.07.2005 № 362 "Protocol of diagnostics and treatment of disease of musculoskeletal system and connective tissue in children ICD-D M00-M25 arthropathies". Immunological examinations included the study of indices of cellular, humoral, monocytic-phagocytic links of immunity, content of cytokines (IL-1,$I L-6)$, detection of SIgA and index of nonspecific protection factor (lysozyme). Assessment of results of researches was carried out using STATISTICA program for Windows (version 10.0), Microsoft Excel 2012, MATLAB 2015 a.
\end{abstract}

Results. In the ReA acute period in children was observed depression of T-system on the background of activation of immunity B-system as the reliable decrease of CD8, CD25 and increase of CD21. There was revealed an increase of IL-6, increase of phagocytic number, spontaneous NBT-test and spontaneous neutrophils activity index. The sIgA level reliably exceeded the standard. At determination of lysozyme the blood serum of patients with ReA in acute period was revealed its deficiency comparing with the standard.

In 9-12 months after the beginning of disease in subgroup of children with prolonged and relapsing clinical course was preserved the increase of IL-6 level and decrease of CD8, CD25 and increase of CD21, increase of sIgA and low content of lysozyme. The indicators of the favorable ReA outcome (remission) are: normalization of indices of T- and B-cellular link of immunity, IL-6, sIgA and lysozyme.

\section{Conclusions.}

1. In the ReA acute period was detected the decrease of CD8, CD25, increase of CD21and IL-6. The phagocytic link of immunity functions in the hypercompensation mode with emaciation (decompensation) phenomena. The sIgA content is increased and lysozyme level is decreased.

2. In 9-12 months after the beginning of disease in subgroup of children with remission was detected normalization of indices of T- and B-cellular links of immunity IL-6, sIgA and lysozyme. In subgroup of children with prolonged and relapsing clinical course was preserved increase of CD21, IL-6, sIgA and decrease of CD8, CD25 and lysozyme Keywords: reactive arthritis, children, cellular and humoral immunity, cytokines, secretory immunoglobulin A, lysozyme 
Установлены особенности нарушений иммунологического гомеостаза у детей, больных реактивными артритами (РеА) в остром периоде. Через 9-12 месяцев от начала заболевания в подгруппе детей с ремиссией отмечена нормализация показателей клеточного звена иммунитета, интерлейкин - 6 (ИЛ-6, sIgA и лизоцима. Неблагоприятный исход РеА характеризовался повышением CD21, ИЛ-6, sIgA и снижением CD8, CD25, лизочима

Ключевые слова: реактивный артрит, дети, клеточный и гуморальный иммунитет, цитокины, секреторный иммуноглобулин А, лизоцим

\section{Introduction}

The diseases of musculoskeletal system are considered throughout the world as the most spread pathologies of the modern society. According to the WHO prognoses to the 2020 year $20 \%$ of human population will suffer from arthritis [1,2].

In different countries the ReA frequency is 8 $41 \%$. The prevalence of inflammatory diseases of joints in children is 75 cases for 100000 of children population. In the structure of rheumatic diseases of children to 14 years old ReA consists $56 \%$ [3].

ReA diagnostics in children remains difficult. The diversity of clinical manifestations and variability of the ReA clinical course often result in diagnostic mistakes, inopportune beginning of etiopathogenetic therapy and, as a consequence, chronization of pathological process or ReA and transformation into the other chronic diseases of joints.

Despite the existing studies of ReA etiology and pathogenesis the problems of the state of immune system and nonspecific protection factors in children with ReA are not completely considered, so, the further study is needed [4].

\section{Substantiation of research}

ReA pathogenetic mechanisms are not completely clear [5-7]. There are scientific researches that prove the participation of cytokines in pathogenesis of rheumatic diseases, confirming the most spread hypothesis of ReA pathogenesis based on cytokines imbalance [8, 9]. Last years there appeared the scientific researches about participation not only cytokines but also neutrophils in pathogenesis of rheumatic diseases [10]. There is also an opinion that in ReA development take part the T-cellular mechanisms, neutrophils and cytokines [11].

Among the different factors, that characterize the protective-adaptive reactions of organism at infectious process, the main role belongs to immunological mechanisms not only specific but also the nonspecific ones. That is why, it is necessary to carry out the research of nonspecific protection factors including lysozyme. Lysozyme is an enzyme that destructs the mucopolysaccharides of bacterial membranes. Lysozyme system is the probable link for appearance of the competitive relations with specific immunity [12, 13]. Although in literature is available an information about changes in immune status of patients with ReA there are no data about the state of nonspecific protection factors at ReA, especially lysozyme.

So, the actual problem is the study of the state of immunological reactivity and nonspecific protection factor (lysozyme) for determination of prognostic factors for diagnostics of ReA clinical course.

\section{Aim of research}

An improvement of diagnostics and prognostication of ReA clinical course in children on the base of studying the immunological reactivity and nonspecific protection factor (lysozyme).

\section{Materials and methods of research}

Examination of children was carried out in the municipal children's cardiorheumatologic department of MHPI "Kharkov municipal children's clinical hospital № 24” and municipal children’s polyclinic of the Kharkov city (№ 1, 2, 7, 12, 13, 14, 23).

40 children with ReA underwent immunological examinations, detection of $\operatorname{sig} \mathrm{A}$ in the saliva and lysozyme in the blood serum in acute period and in 9 12 months after the beginning of disease. 19 children $(47,5 \%)-2-6$ years old, 21 children $(52,5 \%)-7-14$ years old. Boys $-22(55,0 \%)$, girls $-18(45,0 \%)$. The mean age of children in group was 7,2 $\pm 0,32$. The control group included 32 healthy children. The mean age of children in group was $7,4 \pm 0,54$.

The ReA diagnosis was set according to the order of Ukrainian MHP of 19.07.2005 № 362 "Protocol of diagnostics and treatment of disease of musculoskeletal system and connective tissue in children ICD-D M00-M25 arthropathies".

Immunological examinations included the study of indices of cellular, humoral, monocytic-phagocytic links of immunity, content of cytokines (IL-1 $\beta$, IL-6). In the cellular link of immunity the lymphocytes subpopulations (CD3+, CD4+-, CD8+, CD25, CD21) were determined by the method of membrane immunofluorescence with monoclonal antibodies. T-active lymphocytes were determined by the method of rosette creation. The determination of serum immunoglobulins of A, M, G classes was carried out by spectrophotometric method. Monocytic-phagocytic link of immunity was assessed taking into account the phagocytic and metabolic activity of the blood leukocytes using the determination of phagocytic number (PN), spontaneous and induced NBT-test. For assessment of cytokine status in examined patients were determined the IL-1 $\beta$ (series № 231014 23.10.2014) and IL-6 (series № 097 17.11.2014) levels the in blood serum by "sandwich"-method of solid-phase immunosorbent analysis (ISA) using monoclonal antibodies and the set of reagents produced by the firm "Cytokine" (SentPetersburg, Russia). 
For sIgA study was carried out the sampling of saliva from the oral cavity into the special container "eppendorf" on empty stomach, in the morning in amount of $0,5-1 \mathrm{ml}$.

The $\operatorname{sig}$ A determination is based on the use of sandwich"- variant of solid-phase immunosorbent analysis. The study was carried out with the use of laboratory set of reagents for immunosorbent determination of secretory IgA in the biological liquids "Secretory IgA-ISA» of «HEMA» Ltd (№ FSR 2009/06385 of December, 16, 2009 year).

For quantitative determination of lysozyme was used the blood serum. In this test was used the "sandwich" method of ISA analysis with two specific antibodies to the human lysozyme. The research was carried out using laboratory set Lysozym ELISA Kit immundiagnostic AG (Valid from 06.08.2014).

Assessment of the received results was carried out with the help of STATISTICA program for Windows (version 10.0), Microsoft Excel 2012, MATLAB 2015a. The comparison of quantitative indices in studied groups was realized using nonparametric criteria: MannWhitney, Kruskal-Wallis, ANOVA, $\chi^{2}$, median test. The comparison of studied indices in the dynamics after the end of treatment was carried out with the help of Wilcoxon criterion.

\section{Results of researches}

At the study of immunological reactivity and nonspecific protection factor (Table 1) was detected the reliable increase of B-lymphocytes (CD 21) $(\mathrm{p}<0,01)$, sIgA $(p<0,01)$ IL-6 $(p<0,01)$, phagocytic number $(p<0,01)$, spontaneous NBT-test $(p<0,001)$ and spontaneous neutrophils activity index $(\mathrm{p}<0,01)$. The decrease of T-lymphocytes-suppressors (CD8), activated T-lymphocytes (CD25) and lysozyme $(\mathrm{p}<0,01)$.

In 9-12 months after the beginning of disease (Table 2) was detected the reliable increase of $\mathrm{CD} 8$, CD 25, lysozyme $(p<0,01)$. Decrease of CD $21(p<0,05)$, IL-6 $(\mathrm{p}<0,05)$ and $\operatorname{sIg} A(\mathrm{p}<0,01)$.

At comparison of induces of immunological activity and nonspecific protection factors in children with ReA in 9-12 months after the beginning of disease (Table 3 ) in the subgroup of children with prolonged and relapsing clinical course the CD8 $(\mathrm{p}<0.01), \mathrm{CD} 25$ $(p<0.01)$, lysozyme $(p<0.05)$ were reliably decreased and CD21 ( $<<0.05), \operatorname{sig} A(p<0.05)$ were increased comparing with the subgroup of children in the period of remission.

Table 1

Indices of immunological reactivity and nonspecific protection factor (lysozyme) in children with ReA with the acute clinical course

\begin{tabular}{|c|c|c|c|}
\hline Index & $\begin{array}{l}\text { Acute clinical course } \\
\qquad \mathrm{n}=40\end{array}$ & $\begin{array}{c}\text { Control group } \\
n=23\end{array}$ & $\mathrm{p}$ \\
\hline $\mathrm{CD} 3, \%$ & $66,0(58,9 ; 71,2)$ & $67,0(62,4 ; 72,6)$ & $\mathrm{p}>0,05$ \\
\hline $\mathrm{CD} 3$, thousand & $1,8(1,3 ; 2,6)$ & $2,2(1,3 ; 2,9)$ & $\mathrm{p}>0,05$ \\
\hline $\mathrm{CD} 4, \%$ & $39,0(34,7 ; 42,0)$ & $38,0(34,4 ; 41,0)$ & $\mathrm{p}>0,05$ \\
\hline CD4, thousand & $1,1(0,8 ; 1,6)$ & $1,2(0,7 ; 1,7)$ & $\mathrm{p}>0,05$ \\
\hline $\mathrm{CD} 8, \%$ & $25,5(24,0 ; 29,0)$ & $28,0(26,0 ; 33,0)$ & $\mathrm{p}<0,01$ \\
\hline CD8, thousand & $0,7(0,5 ; 1,1)$ & $0,9(0,6 ; 1,3)$ & $\mathrm{p}<0,05$ \\
\hline $\mathrm{CD} 21, \%$ & $20,0(17,0 ; 24,0)$ & $18,0(13,8 ; 21,0)$ & $\mathrm{p}<0,01$ \\
\hline CD21, thousand & $0,5(0,3 ; 1,1)$ & $0,6(0,3 ; 0,9)$ & $\mathrm{p}>0,05$ \\
\hline T-lymphocytes CD25, \% & $17,0(11,9 ; 19,0)$ & $17,0(14,4 ; 21,6)$ & $\mathrm{p}>0,05$ \\
\hline T-lymphocytes CD25, thousand & $0,5(0,4 ; 1,1)$ & $0,7(0,5 ; 1,3)$ & $\mathrm{p}<0,01$ \\
\hline IL- $1 \beta, \mathrm{pg} / \mathrm{ml}$ & $16,2(3,62 ; 70,8)$ & $18,7(6,2 ; 35,1)$ & $\mathrm{p}>0,05$ \\
\hline IL-6, pg/ml & $5,6(1,6 ; 29,6)$ & $2,1(0,85 ; 5,7)$ & $\mathrm{p}<0,01$ \\
\hline Phagocytic number & $3,8(2,8 ; 4,2)$ & $3,5(1,8 ; 3,9)$ & $\mathrm{p}<0,01$ \\
\hline Spontaneous NBT, \% & $31,0(24,9 ; 34,1)$ & $9,7(8,0 ; 11,0)$ & $\mathrm{p}<0,001$ \\
\hline Stimulated HBT, $\%$ & $73,0(62,5 ; 78,0)$ & $71,0(52,6 ; 76,2)$ & $\mathrm{p}>0,05$ \\
\hline Spontaneous neutrophils activity index, unit & $0,6(0,5 ; 0,8)$ & $0,1(0,1 ; 0,2)$ & $\mathrm{p}<0,01$ \\
\hline Stimulated neutrophils activity index, unit & $1,5(0,9 ; 1,6)$ & $1,4(1,1 ; 1,5)$ & $\mathrm{p}>0,05$ \\
\hline Ig A (serum), g/l & $1,3(0,9 ; 1,7)$ & $1,1(0,9 ; 1,5)$ & $\mathrm{p}>0,05$ \\
\hline Ig M (serum), g/l & $0,99(0,8 ; 1,2)$ & $0,9(0,4 ; 1,1)$ & $\mathrm{p}>0,05$ \\
\hline Ig G (serum), g/l & $10,5(9,1 ; 11,5)$ & $10,1(8,2 ; 11,7)$ & $\mathrm{p}>0,05$ \\
\hline $\mathrm{sIgA}, \mathrm{mg} / \mathrm{ml}$ & $292,6(82,1 ; 379,3)$ & $104,5(25,9 ; 243,7)$ & $\mathrm{p}<0,01$ \\
\hline Lysozyme, ng/ml & $229,5(131,3 ; 566,0)$ & $1250,0(669,9 ; 4217,4)$ & $\mathrm{p}<0,01$ \\
\hline
\end{tabular}


Table 2

Indices of immunological reactivity and nonspecific protection factor (lysozyme) in children with ReA with the acute clinical course and in 9-12 months after the beginning of disease

\begin{tabular}{|c|c|c|c|}
\hline Index & $\begin{array}{l}\text { Acute clinical course } \\
\qquad \mathrm{n}=40\end{array}$ & $\begin{array}{l}\text { In 9-12 months } \\
n \mathrm{n}=40\end{array}$ & $\mathrm{p}$ \\
\hline $\mathrm{CD} 3, \%$ & $66,0(58,9 ; 71,2)$ & $68,0(64,0 ; 72,0)$ & $\mathrm{p}>0,05$ \\
\hline CD3, thousand & $1,8(1,3 ; 2,6)$ & $1,8(1,4 ; 2,8)$ & $\mathrm{p}>0,05$ \\
\hline $\mathrm{CD} 4, \%$ & $39,0(34,7 ; 42,0)$ & $40,0(37,0 ; 41,0)$ & $\mathrm{p}>0,05$ \\
\hline CD4, thousand & $1,1(0,8 ; 1,6)$ & $1,1(0,9 ; 1,7)$ & $\mathrm{p}>0,05$ \\
\hline $\mathrm{CD} 8, \%$ & $25,5(24,0 ; 29,0)$ & $28,0(26,1 ; 30,0)$ & $\mathrm{p}<0,01$ \\
\hline CD8, thousand & $0,7(0,5 ; 1,1)$ & $0,8(0,6 ; 1,2)$ & $\mathrm{p}>0,05$ \\
\hline $\mathrm{CD} 21, \%$ & $20,0(17,0 ; 24,0)$ & $19,0(18,0 ; 21,0)$ & $\mathrm{p}<0,05$ \\
\hline CD21, thousand & $0,5(0,3 ; 1,1)$ & $0,5(0,4 ; 0,9)$ & $\mathrm{p}>0,05$ \\
\hline T-lymphocytes CD25, \% & $17,0(11,9 ; 19,0)$ & $18,0(16,1 ; 22,0)$ & $\mathrm{p}<0,01$ \\
\hline T-lymphocytes CD25, thousand & $0,5(0,4 ; 1,1)$ & $0,5(0,4 ; 0,8)$ & $\mathrm{p}>0,05$ \\
\hline IL-1 $\beta, \mathrm{pg} / \mathrm{ml}$ & $16,2(3,62 ; 70,8)$ & $11,5(6,4 ; 51,4)$ & $\mathrm{p}>0,05$ \\
\hline IL-6, pg/ml & $5,6(1,6 ; 29,6)$ & $3,3(1,25 ; 13,08)$ & $\mathrm{p}<0,05$ \\
\hline Phagocytic number & $3,8(2,8 ; 4,2)$ & $3,9(3,6 ; 4,2)$ & $\mathrm{p}>0,05$ \\
\hline Spontaneous NBT,\% & $31,0(24,9 ; 34,1)$ & $26,0(13,5 ; 38,9)$ & $\mathrm{p}>0,05$ \\
\hline Spontaneous neutrophils activity index, unit & $0,6(0,5 ; 0,8)$ & $0,6(0,3 ; 0,7)$ & $\mathrm{p}>0,05$ \\
\hline Stimulated NBT, \% & $73,0(62,5 ; 78,0)$ & $74,0(69,0 ; 77,0)$ & $\mathrm{p}>0,05$ \\
\hline Stimulated neutrophils activity index, unit & $1,5(0,9 ; 1,6)$ & $1,5(1,4 ; 1,5)$ & $\mathrm{p}>0,05$ \\
\hline Ig A (serum), g/l & $1,3(0,9 ; 1,7)$ & $1,5(0,9 ; 1,7)$ & $\mathrm{p}>0,05$ \\
\hline Ig M (serum), g/l & $0,99(0,8 ; 1,2)$ & $1,1(0,9 ; 1,2)$ & $\mathrm{p}>0,05$ \\
\hline Ig G (serum), g/l & $10,5(9,1 ; 11,5)$ & $10,3(8,4 ; 11,6)$ & $\mathrm{p}>0,05$ \\
\hline $\mathrm{sIgA}, \mathrm{mg} / \mathrm{ml}$ & $292,6(82,1 ; 379,3)$ & $166,4(28,6 ; 424,6)$ & $\mathrm{p}<0,01$ \\
\hline Lysozyme, ng/ml & $229,5(131,3 ; 566,0)$ & $1047,5(244,0 ; 3395,0)$ & $\mathrm{p}<0,01$ \\
\hline
\end{tabular}

Table 3

Indices of immunological reactivity and nonspecific protection factor in children with ReA in 9-12 month after the beginning of disease depending on clinical course

\begin{tabular}{|c|c|c|c|}
\hline Indices & $\begin{array}{c}\text { Remission } \\
\mathrm{n}=31(77,5 \%)\end{array}$ & $\begin{array}{c}\text { Prolonged and relapsing } \\
\text { clinical course } \\
\mathrm{n}=9(22,5 \%)\end{array}$ & $\mathrm{p}$ \\
\hline $\mathrm{CD} 8, \%$ & $28,0(26,1 ; 30,0)$ & $25,3(24,0 ; 29,0)$ & $\mathrm{p}<0.01$ \\
\hline $\mathrm{CD} 25, \%$ & $18,0(16,1 ; 22,0)$ & $17,0(11,9 ; 19,0)$ & $\mathrm{p}<0.01$ \\
\hline CD 21, \% & $19,0(18,0 ; 21,0)$ & $20,0(17,0 ; 24,0)$ & $\mathrm{p}<0.05$ \\
\hline ИЛ-6, pg/ml & $3,1(1,25 ; 13,08)$ & $5,4(1,6 ; 29,6)$ & $\mathrm{p}<0.05$ \\
\hline SIgA, $\mathrm{mg} / \mathrm{ml}$ & $102,0(28,1 ; 398,8)$ & $202,2(105,6 ; 469,9)$ & $\mathrm{p}<0.05$ \\
\hline Lysozyme, $\mathrm{ng} / \mathrm{ml}$ & $1350,0(625,5 ; 3400,0)$ & $370,0(155,5 ; 565,0)$ & $\mathrm{p}<0.05$ \\
\hline
\end{tabular}

\section{Discuss of the results of research}

In the ReA acute period in children was detected the depression of T-system on the background of activation of immunity B-system as the reliable decrease of relative and absolute content of T-lymphocytes-suppressors (CD8), absolute number of active T-lymphocytes (CD25) and increase of relative content of B-lymphocytes (CD21). There was revealed an increase of proinflammatory cytokine IL-6 comparing with the standard.

As to the functional activity of the phagocytizing blood cells in the ReA acute period, there was detected the reliable increase of phagocytic number, spontaneous
NBT-test and spontaneous neutrophils activity index. It testifies to the fact that despite the high functional activity of immunity phagocytic link, its reserves are insufficient for the full-fledged elimination of organism from antigenic load. At the study of humoral immunity was detected that the mean indices of the serum Ig A, M, G did not differ from the referent values $(\mathrm{p}>0,05)$. At the study of $\operatorname{sIg} A$ content was detected that in the ReA acute period the sIgA level reliably exceeded the standard $(\mathrm{p}<0.01)$. At determination of lysozyme content in the blood serum of patients with ReA in the acute period was revealed its deficiency comparing with the standard $(p<0,01)$ (Table 1). 
In 9-12 months after the beginning of disease at the study of cellular immunity indices was detected the reliable increase of CD8 comparing with the group of patients with the acute clinical course $(p<0,01)$. The index of CD21 decreased $(\mathrm{p}<0,05)$ and index of CD25 increased $(\mathrm{p}<0,01)$. At analysis of cytokine profile IL-6 level reliably decreased comparing with the ReA acute clinical course $(p<0,05)$. Indices of the phagocytizing blood cells activity did not reliably change and did not differ from the phagocytosis of the acute group that testifies to the preserving imbalance in phagocytosis processes. The comparative analysis of sIgA content in patients with ReA in 9-12 months after the beginning of disease demonstrated the reliable decrease comparing with initial data $(p<0,01)$. The lysozyme content in the blood serum of patients with ReA in 9-12 months after the beginning of disease reliably increased $(\mathrm{p}<0,01)$ (Table 2$)$.

In $31(77,5 \%)$ children in 9-12 months after the beginning of disease was detected remission, in $9(22,5 \%)$ children was detected the prolonged and relapsing clinical course. In the subgroup of children with prolonged and relapsing clinical course (Table 3) was preserved the increase of IL-6 level, disorder of T- and B-systems of immunity as the reliable decrease of CD8, CD25 $(p<0.01)$ and increase of CD21 $(\mathrm{p}<0.05)$, increase of $\operatorname{sIgA}(\mathrm{p}<0.05)$ and the low content of lysozyme $(\mathrm{p}<0.05)$ that results in formation of hypersensitization of organism. The normalization of indices of T- and B-cellular link of immunity, IL-6, sIgA and lysozyme testifies to the favorable ReA outcome (remission).

\section{Conclusions}

1. In the ReA acute period was detected the decrease of CD8, CD25 and increase of CD21, I1-6, sIgA. Phagocytic link of immunity functions in the hypercompensation mode with emaciation (decompensation) phenomena.

2. The acute clinical course of ReA is characterized with lysozyme decrease in the blood serum.

3. In 9-12 months after the beginning of disease in the subgroup of children with remission was detected the normalization of indices of T- and B-cellular links of immunity, IL-6, sIgA and lysozyme.

4. In subgroup of children with prolonged and relapsing clinical course was preserved the increase of CD21, IL-6, sIgA and decrease of CD8, CD25 and lysozyme.

\section{References}

1. Natal'chenko, G. I. Jetiopatogenez, klinika, diagnostika reaktivnyh artritov u detej: (obzor literatury) [Text] / G. I. Natal'chenko // Perinatologija i pediatrija. - 2011. - Issue 2. - P. 110-112.

2. Omel'chenko, L. I. Aktual'nye voprosy vtorichnoj profilaktiki sustavnogo sindroma u detej [Text] / L. I. Omel'chenko, E. A. Oshljanskaja // Sovremennaja pediatrija. - 2010. - Issue 1. - P. 43-47.

3. Marushko, T. V. Reaktyvni artropatii' u ditej [Text] / T. V. Marushko // Zdorov'ja Ukrai'ny. - 2012. - Issue 2. - P. 43-44.
4. Berezhnyj, V. V. Klinichna revmatologija dytjachogo viku [Text]: navch. pos. / V. V. Berezhnyj, T. V. Marushko, Ju. V. Marushko. - Cherkasy: v-c' Chabatenko Ju., 2009. - 192 p.

5. Kim, P. S. Reactive Arthritis: A Review [Text] / P. S. Kim, T. L. Klausmeier, D. P. Orr // Journal of Adolescent Health. - 2009. - Vol. 44, Issue 4. - P. 309-315. doi: 10.1016/ j.jadohealth.2008.12.007

6. Rihl, M. Reactive arthritis [Text] / M. Rihl, A. Klos, L. Köhler, J. G. Kuipers // Best Practice \& Research Clinical Rheumatology. - 2006. - Vol. 20, Issue 6. - P. 1119-1137. doi: 10.1016/j.berh.2006.08.008

7. Selmi, C. Diagnosis and classification of reactive arthritis [Text] / C. Selmi, M. E. Gershwin // Autoimmunity Reviews. - 2014. Vol. 13, Issue 4-5. - P. 546-549. doi: 10.1016/j.autrev.2014.01.005

8. Spas'ka, G. O. Reaktyvnyj artryt: suchasnyj pogljad na problemu [Text] / G. O. Spas'ka // Ukrai'ns'kyj medychnyj chasopys. - 2011. - Issue 6. - P. 42-48.

9. Gaponova, T. V. Izuchenie citokinovogo statusa bol'nyh reaktivnym artritom [Text] / T. V. Gaponova, A. M. Lila, T. G. Shemerovskaja et. al // Medicinskaja immunologija. 2008. - Issue 2-3. - P. 167-172.

10. Chaplygina, L. N. Kliniko-diagnosticheskoe znachenie laktoferrina i molekul citokinov u bol'nyh reaktivnymi artritami [Text]: avtoref. dis. ... kand. med. nauk / L. N. Chaplygina. - Ja., 2007. - 142 p.

11. Lebec', I. S. Harakterystyka imunologichnyh zmin na riznyh etapah rozvytku juvenil'nogo revmatoi'dnogo ta reaktyvnogo artrytiv u ditej [Text] / I. S. Lebec', N. O. Pan'ko, I. M. Nelina // Perynatologyja y pedyatryja. - 2014. - Issue 2. - P. 64-67.

12. Brjazgunov, I. P. Dlitel'nye subfebrilitety u detej (klinika, jetiologija, patogenez i lechenie) [Text] / I. P. Brjazgunov. - 2-nd ed. - M.: OOO «Medicinskoe informacionnoe agentstvo», 2008. $-240 \mathrm{p}$.

13. Julish, E. I. Faktory mestnogo immuniteta pri respiratornyh infekcijah i metody ih aktivacii [Text] / E. I. Julish // Zdorov'e rebenka. - 2010. - Issue 5. - P. 77-83.

\section{References}

1. Natal'chenko, G. I. (2011). Jetiopatogenez, klinika, diagnostika reaktivnyh artritov u detej: (obzor literatury). Perinatologija i pediatrija, Issue 2, 110-112.

2. Omel'chenko, L. I., Oshljanskaja, E. A. (2010). Aktual'nye voprosy vtorichnoj profilaktiki sustavnogo sindroma $\mathrm{u}$ detej. Sovremennaja pediatrija, 1, 43-47.

3. Marushko, T. V. (2012). Reaktyvni artropatii' u ditej. Zdorov'ja Ukrai'ny, 2, 43-44.

4. Berezhnyj, V. V., Marushko, T. V., Marushko, Ju. V. (2009). Klinichna revmatologija dytjachogo viku. Cherkasy: v-c' Chabatenko Ju., 192.

5. Kim, P. S., Klausmeier, T. L., Orr, D. P. (2009). Reactive Arthritis: A Review. Journal of Adolescent Health, 44 (4), 309-315. doi: 10.1016/j.jadohealth.2008.12.007

6. Rihl, M., Klos, A., Köhler, L., Kuipers, J. G. (2006). Reactive arthritis. Best Practice \& Research Clinical Rheumatology, 20 (6), 1119-1137. doi: 10.1016/j.berh.2006.08.008

7. Selmi, C., Gershwin, M. E. (2014). Diagnosis and classification of reactive arthritis. Autoimmunity Reviews, 13 (4-5), 546-549. doi: 10.1016/j.autrev.2014.01.005

8. Spas'ka, G. O. (2011). Reaktyvnyj artryt: suchasnyj pogljad na problemu. Ukrai'ns'kyj medychnyj chasopys, 6, 42-48. 
9. Gaponova, T. V., Lila, A. M., Shemerovskaja, T. G. et. al. (2008). Izuchenie citokinovogo statusa bol'nyh reaktivnym artritom. Medicinskaja immunologija, 2-3, 167-172.

10. Chaplygina, L. N. (2007). Kliniko-diagnosticheskoe znachenie laktoferrina i molekul citokinov u bol'nyh reaktivnymi artritami. Jaroslavl', 142.

11. Lebec', I. S., Pan'ko, N. O., Nelina, I. M. (2014). Harakterystyka imunologichnyh zmin na riznyh etapah rozvytku juvenil'nogo revmatoi'dnogo ta reaktyvnogo artrytiv u ditej. Perynatologyja y pedyatryja, 2, 64-67.

12. Brjazgunov, I. P. (2008). Dlitel'nye subfebrilitety u detej (klinika, jetiologija, patogenez i lechenie). Moscow: OOO «Medicinskoe informacionnoe agentstvo», 240.

13. Julish, E. I. (2010). Faktory mestnogo immuniteta pri respiratornyh infekcijah i metody ih aktivacii. Zdorov'e rebenka, $5,77-83$.

Рекомендовано до публікаџіï д-р мед. наук Сіренко I. О. Дата надходження рукопису 24.02.2016

Savvo Vladimir, Candidate of Medical Sciences, Associate Professor, Department of pediatrics, Kharkiv Medical Academy of Postgraduate Education, Korchagintsev str., 58, Kharkiv, Ukraine, 61176 E-mail: savvovm50@gmail.com

Tverdohleb Tat'jana, Assistant, Department of Pediatric Pulmonology and Tuberculosis, Kharkiv Medical Academy of Postgraduate Education, Korchagintsev str., 58, Kharkiv, Ukraine, 61176

УДК 616.441-089.87: 616.441-006.6: 615.849.2

DOI: $10.15587 / 2313-8416.2016 .64975$

\section{КОМБІНОВАНЕ ЛІКУВАННЯ ВИСОКОДИФЕРЕНЦІЙОВАНОГО РАКУ ЩИТОВИДНОЇ ЗАЛОЗИ: В ФОКУСІ РЕКОМБІНАНТНИЙ ЛЮДСЬКИЙ ТИРЕОТРОПІН-АЛЬФА}

\section{(ㄷ) П. П. Зінич}

У наведеній роботі представлені результати дослідження з вивчення переваг застосування нового засобу фармакотерапевтичної корекції після тиреоїдектомії-рекомбінантного людського тиреотропіну-альфа (рлТТГ). Встановлено, щзо використання рлТТГ підвищує ефективність абляції залишкової тиреоїдної тканини порівняно з традииійним методами підготовки (попередня відміна прийому препаратів левотироксину натрію), підвищує суб 'єктивну оцінку сприйняття якості життя пацієнтами

Ключові слова: високодиферениійований рак щуитовидної залози, рекомбінантний людський тиреотропін-альфа, якість життя, тиреоглобулін, аблячія, рідіойодтерапія

Aim. An assessment of the effectiveness of treatment and also the detection of advantages of prescription of the recombinant human thyrotropin-alpha (rhTTH) in postoperative period in patients with the highly differentiated cancer of thyroid gland (HDCTG) comparing with traditional method of preparation (cancellation of the thyroid hormones) to the treatment using radioactive iodine.

Methods. There was carried out an analysis of the treatment of 100 patients with HDCTG: the control group56 patients (standard tactics), the main group - 44 patients (the use of rhTTH). There was carried out the scanning of all the body in 48 hours after administration of $150 \mathrm{MBc} 1311$, was detected the concentration of thyroglobulin and antibodies to it, the level of thyrotropic hormone, was carried out the ultrasound of neck and also questioning about the life quality.

Results. The comparative analysis of the data of studied groups demonstrated the reliably less number of isotope accumulation nidi in persons whose preparation was carried out with the help of rhTTH, that is the absence of visible catch in $25 \%$ of cases in patients from the category of low risk (in 5,7 times higher than in analogous cohort of the control group - 4,4\%) and in 7,1\% - in patients from the high risk group. The number of cases of the minimal visible catch $<0,1 \%$ in patients of the high risk category is reliably higher comparing with the control one $(78,1 \%$ and $56,1 \%$ respectively, $P<0,01)$. The level of stimulated serum thyroglobulin $>2,0 \mathrm{ng} / \mathrm{ml}$ was detected in $3,1 \%$ of cases in the main group whereas in the control one - 13,1\%; within 1,0-2,0 $\mathrm{ng} / \mathrm{ml}$ was detected reliably less often in the main group: $8,3 \%$ in the low risk patients and 12,5\%-in the high risk ones comparing with the control group (28,6 \% and 31,7\% respectively). The effective decrease of thyroglobulin level in 6-8 months after radioiodine therapy was detected in 22 (91,7\%) patients of the main low risk group and in 27 (84,4\%) - ones of the high risk that is reliably higher than in the control group $(60,0 \%$ and $53,7 \%$ respectively, $P<0,01)$. In the main group was not observed any clinical relapse of disease or persistence of pathological tumor process, in the control group on the contrary - 2 clinical relapses (4,9\%) and 4 cases (9,7\%) of persistence of disease. In the main group nobody needed the repeated operation during 6 months after radioiodine therapy because of absence of the regional metastases of papillary carcinoma. The negative assessment of health was observed in 10,7\% of cases in the control group and was not fixed in the main one. The positive assessment of health was observed in 63,6\% of patient who took recombinant TTH comparing with the control group - 21,4\%. 